\title{
Impact of malocclusion on oral health-related quality of life of preschool children
}

\author{
Impacto da maloclusão na qualidade de vida relacionada à saúde bucal em pré-escolares
}

\author{
Guilherme Nascimento da ROSA ${ }^{1}$ \\ Bruna Cássia Schmit BUZZATI ${ }^{1}$ \\ Chaiana PIOVESAN ${ }^{2}$ \\ Fausto Medeiros MENDES 3 \\ Marta Dutra Machado OLIVEIRA ${ }^{1}$ \\ Thiago Machado ARDENGHI ${ }^{1}$
}

\section{ABSTRACT}

\section{Objective}

This study assessed the relationship of dental malocclusion with COHRQoL considering socioeconomic backgrounds and clinical factors.

\section{Methods}

A survey was carried out in Santa Maria, Brazil, during the National Children's Vaccination Day. The sample comprised 478 children aged 12 to 59 months. Fifteen trained and calibrated examiners evaluated the presence of anterior malocclusion traits (AMT) - anterior open bite, overjet and sealing lip. COHRQoL was measured through overall scores of the Brazilian version of ECOHIS (Early Childhood Oral Health Impact Scale). The assessment of association used adjusted Poisson regression models.

\section{Results}

The unadjusted assessment observed age, untreated dental caries and anterior open bite as the main covariates of the overall ECOHIS score. After the adjustment, the presence of anterior open bite had a negative impact on COHRQoL. There was no association between overjet and sealing lip with COHRQoL.

\section{Conclusion}

In conclusion, anterior open bite present a negative impact on COHRQOL.

Indexing terms: Child. Epidemiology. Malocclusion. Quality of life.

\section{RESUMO}

\section{Objetivos}

Este estudo avaliou o impacto da maloclusão dentária na qualidade de vida relacionada à saúde bucal, considerando fatores socioeconômicos e condições clínicas.

\section{Metodos}

Um estudo foi realizado em Santa Maria, Brasi, durante a Campanha Nacional de Multivacinação Infantil. A amostra compreendeu 478 crianças na faixa etária de 12 a 59 meses. Quinze examinadores treinados e calibrados avaliaram a presença de maloclusão na região anterior - mordida aberta anterior, overjet e selamento labial. na qualidade de vida relacionada à saúde bucal foi mensurada por meio de escores totais da versão em português do questionário ECOHIS (Early Childhood Oral Health Impact Scale). Para verificar as possíveis variáveis associadas foram aplicados modelos de regressão de Poisson.

\section{Resultados}

O modelo não ajustado revelou associação da idade, cárie dentária não tratada e e mordida aberta anterior aos escores totais do ECOHIS. Após o ajuste, verificou-se que mordida aberta anterior teve um impacto negativo na qualidade de vida relacionada à saúde bucal. Não houve associação entre a presença de overjet e elamento labial à qualidade de vida relacionada à saúde bucal.

\section{Conclusão}

Pode-se concluir que que mordida aberta anterior teve um impacto negativo na qualidade de vida relacionada à saúde bucal.

Termos de indexação: Criança. Epidemiologia. Má oclusão. Qualidade de vida.

\footnotetext{
${ }^{1}$ Universidade Federal de Santa Maria, Faculdade de Odontologia, Departamento de Estomatologia. Av. Roraima, 1000, Cidade Universitária, Camobi, Santa Maria, RS, Brasil. Correspondência para / Correspondence to: TM ARDENGHI. Email: <thiardenghi@hotmail.com>.

2 Centro Universitário Franciscano, Faculdade de Odontologia. Santa Maria, RS, Brasil.

${ }^{3}$ Universidade de São Paulo, Faculdade de Odontologia, Departamento de Odontopediatria. São Paulo, SP, Brasil.
} 


\section{INTRODUCTION}

Dental malocclusion can produce aesthetic alterations in teeth or face, and functional changes involving the mastication, the phonation and occlusion ${ }^{1-3}$. In Brazil, it has been shown that the prevalence of malocclusion can be considered a public health problem, with $22.01 \%$ of children under 5 years old presenting slight occlusal problem and $14.45 \%$ had moderate or severe problem ${ }^{4}$.

However, the exclusively use of such normative indicators has been considered inadequate for measuring oral health and orthodontics treatment needs ${ }^{5-6}$. It has been proposed that any criteria for definition of treatment needs should take into consideration how the health/ disease interferes with children's daily activities and quality of life $\mathrm{e}^{7-8}$. Nevertheless, assessing the self-report of oral health-related quality of life (OHRQoL) has been widely advocated as an adjunct to clinical examinations documenting the full impact of oral disorders on children's daily performance ${ }^{8}$. For this purpose, OHRQoL instruments have been developed for different age-groups and populations; the Early Childhood Oral Health Impact Scale $(\mathrm{ECOHIS})^{7}$ is one of the instruments. It is a proxy measure of COHRQoL designed to assess the negative impact of oral disorders on quality of life among underfive-year-old children. The ECOHIS was developed in the United States but previous studies confirmed its validity and reliability in Brazil|-9.

There are few studies assessing the negative impact of malocclusion on COHRQoL and daily performance, specially using representative sample and taken into consideration the possible confounder effect of other clinical and socioeconomic variables ${ }^{10-11}$. The results of such studies may contribute for a public health perspective, mainly to a full evaluation of treatment outcomes and to the definition of groups with higher levels of orthodontics need, thus instructing public health programs. The purpose of this study was to evaluate prevalence of malocclusion and its effect on OHRQoL of preschool children and their parents.

\section{METHODS}

\section{Ethical aspects}

This study was approved by the Committee for Ethics in Research, of the Federal University of Santa Maria n. 0270.0.243.000-09.

\section{Subjects and study design}

A survey was performed to assess the oral health status of 1 to 5 years-old preschool children in the city of Santa Maria, RS, located in the south of Brazil. The city has 263,403 inhabitants, with 27,520 children under 6 years old. This survey was performed during the National Children's Vaccination Day. According to the Ministry of Health, the vaccination program has had consistently uptake rates above $97 \%$.

To assess prevalence malocclusion, the estimated minimum sample size was calculated assuming the following parameters: prevalence of anterior open-bite estimated at $34 \%{ }^{11}$, a standard error of $5 \%$, confidence level of $95 \%$ and a design effect of 1.2 . To cover nonresponse, the sample was increased by $10 \%$ to 455 mother-child dyads.

A sampling quota was selected from all children attending at health centres in the municipality. For this study, all health centers that possessed a dental chair (15 health centers) were used as sample points. These were the largest health centers in the city, and almost $90 \%$ of children visited these centers at the time that this study was undertaken. The sample was stratified according to the number of children in each area. Dental examiners were distributed throughout 15 health centres in Santa Maria During the survey, each fifth child in the queue for vaccination was invited to participate. If parents did not agree to participate, the next child in the queue was selected ${ }^{12}$.

\section{Data collection}

Data were collected through clinical oral examinations and structured interviews. Children were examined seated on a dental chair using an operating light, a 3-in-1 syringe, plane dental mirror (dental plane mirror $n$. 5, Golgran, São Paulo, SP, Brazil), WHO periodontal probes (WHO - probe - Golgran, São Paulo, SP, Brazil), wet gauze pads and dental floss.

Clinical examination for recording dental caries, dental trauma and malocclusion were performed. The dental examination for dental trauma included only primary maxillary and mandibular incisors. The criteria for traumatic dental injuries used in the Children's Dental Health Survey in UK were adopted ${ }^{13}$. Prevalence and severity of dental caries were measured by the ICDAS criteria ${ }^{14}$. Prevalence of the three most commonly anterior malocclusion traits (AMT) found at preschool were assessed: anterior open bite, overjet, which was measured using a millimeter ruler, was considered as a 
risk factor when it presented values higher than $3 \mathrm{~mm}$. Lip coverage was considered adequate when the lips covered the anterior teeth completely in the at-rest position and inadequate if the majority of the crown height was exposed and visible. Fifteen examiners participated in the study; they had previous experience in oral health surveys and had been trained and calibrated by one benchmark examiner. Theoretical activities with discussion on diagnostic criteria of AMT- based on the diagnostic of photographic image- were performed. Then, a total of 10 children were examined twice by the same examiner, with an interval of two weeks between each examination; interexaminer and intraexaminer kappa values ranged from 0.8 to 0.9 and from 0.8 to 1.0 , respectively.

\section{Socioeconomic and demographic variables}

To obtain socioeconomic data each child's guardian was interviewed using a structured questionnaire. The questionnaire provided information on age, gender, parents' education level, occupation and household income. The educational level compared those fathers and mothers who completed eight years of formal instruction, which in Brazil corresponds to primary school, with those who only completed a lower education (less than eight years of formal education). Household income was measured in terms of the Brazilian minimum wage, a standard for this type of assessment, which corresponded to approximately 280 US dollars during the period of data gathering. Occupational status discriminated the employed and unemployed parents.

\section{Oral Health-related Quality of Life}

The COHRQoL was assessed by the Brazilian version of the ECOHIS ${ }^{8-9}$. It consists of 13 items, including a child impact section (symptoms, function, psychological, self-image/social interaction domains) and a family impact section (parent distress and family function domains). Answers were recorded using a Likert scale with response options coded 0-5 $(0=$ never; $1=$ hardly ever; 2 = occasionally; $3=$ often; 4 = very often; $5=$ don't know). Mean ECOHIS scores were calculated for each domain and for the whole scale as a simple sum of the response codes, after recoding all "Don't know" responses as missing. For those with up to two missing responses in the child section or one in the family section, a score for the missing items was imputed as an average of the remaining items for that section ${ }^{7}$. Parents with missing responses to more than two child items and one family item were excluded from the analysis. Total score had a 0-52 range-the higher the score, the greater the impact of oral health problems and related treatment experiences on OHRQoL of preschool children and their families.

\section{Statistical analyses}

Data analysis was performed using STATA software (Stata 11.1 for Windows; Stata Corporation, College Station, TX, USA) and taking into account the survey design. For this propose, a weight variable was used in the statistical analysis to adjust for the potential bias in the population estimates. The association between the main predictor variable (malocclusion) and the outcomes (domain-specific and overall ECOHIS scores) was assessed using unadjusted and adjusted Poisson regression analysis. This strategy allowed estimating rate ratios (ratio of geometric means) and their respective $95 \%$ confidence interval controlling for potential covariates. We considered only those covariates that presented a $p$-value $\leq 0.20$ in the unadjusted analyses for entry into the multivariate model; they were retained into the final models only if they had a p-value $\leq 0.05$ after adjustment.

\section{RESULTS}

A total of 478 children, $48.5 \%$ boys, were enrolled in the study. Near 5 out of each 10 mothers, and 9 out of each 10 fathers were employed; more than half of families earned less than two Brazilian minimum wages. Prevalence of cavity of caries, dental trauma, overjet ( $\geq 3 \mathrm{~mm})$, sealing lip and anterior open bite were 30.7, 14.1, 13.5, 10.3 and 26.8 respectively (Table 1 ).

Total ECOHIS scores ranged from 0 to 41 with an average of 1.9 (standard error $=0.21$ ). Except for the child section -function domain, responses ranged from "never" (minimum) to "very often" (maximum). The highest mean was for child function domain and the lowest for the child self-image/social interaction and family function domains (Table 2).

The unadjusted assessment observed age, untreated dental caries and anterior open bite as the main covariates of the overall ECOHIS score. Analogous observations were performed for domain-specific ECOHIS scores (Table 3). The adjusted analysis showed that children with anterior open bite and cavity of caries had a negative impact on OHRQoL (Table 3). 
Table 1. Sociodemographic and clinical characteristi

\begin{tabular}{|c|c|c|}
\hline Variables & $n$ & $(\%)$ \\
\hline \multicolumn{3}{|l|}{ Child's gender } \\
\hline Male & 232 & 48.5 \\
\hline Female & 246 & 51.5 \\
\hline \multicolumn{3}{|c|}{ Child's age (months) } \\
\hline $12-23$ & 97 & 20.3 \\
\hline $24-35$ & 89 & 18.6 \\
\hline $36-47$ & 119 & 24.9 \\
\hline $48-59$ & 173 & 36.2 \\
\hline \multicolumn{3}{|c|}{ Household income } \\
\hline$\geq 2 \mathrm{BMW}$ & 174 & 38.6 \\
\hline$<2 \mathrm{BMW}$ & 277 & 61.4 \\
\hline \multicolumn{3}{|c|}{ Mother's schooling } \\
\hline$\geq 8$ years & 268 & 56.8 \\
\hline$<8$ years & 204 & 43.2 \\
\hline \multicolumn{3}{|c|}{ Fathes's schooling } \\
\hline$\geq 8$ years & 247 & 55.4 \\
\hline$<8$ years & 199 & 44.6 \\
\hline \multicolumn{3}{|c|}{ Mother's occupation } \\
\hline Employed & 231 & 49.5 \\
\hline Unemployed & 236 & 50.5 \\
\hline \multicolumn{3}{|c|}{ Father's occupation } \\
\hline Employed & 412 & 90.0 \\
\hline Unemployed & 46 & 10.0 \\
\hline \multicolumn{3}{|c|}{ Cavity of Caries } \\
\hline No & 331 & 69.3 \\
\hline Yes & 147 & 30.7 \\
\hline \multicolumn{3}{|l|}{ Dental trauma } \\
\hline Without & 401 & 85.9 \\
\hline With & 66 & 14.1 \\
\hline \multicolumn{3}{|l|}{ Overjet } \\
\hline$\leq 3 \mathrm{~mm}$ & 308 & 86.5 \\
\hline$>3 \mathrm{~mm}$ & 48 & 13.5 \\
\hline \multicolumn{3}{|l|}{ Lip coverage } \\
\hline Adequate & 417 & 89.7 \\
\hline Inadequate & 48 & 10.3 \\
\hline \multicolumn{3}{|c|}{ Anterior open bite } \\
\hline No & 336 & 73.2 \\
\hline Yes & 123 & 26.8 \\
\hline
\end{tabular}

* BMW= Brazilian Minimum Wage. 
Table 2. Descriptive distribution of total ECOHIS and domains scores. Santa Maria, Brazil ( $n=478$ mother-child dyads).

\begin{tabular}{|c|c|c|c|}
\hline ECOHIS domains & $\begin{array}{c}\text { Mean } \\
(\mathrm{SE})\end{array}$ & $\begin{array}{l}\text { Possible } \\
\text { range }\end{array}$ & Range \\
\hline \multicolumn{4}{|l|}{ Child section } \\
\hline 1. How often has your child had pain in the teeth, mouth, or jaws? (Symptoms) & $0.3(0.03)$ & $0-4$ & $0-4$ \\
\hline How often has your child... because of dental problems or dental treatments? (Function) & $0.5(0.09)$ & $0-16$ & $0-15$ \\
\hline \multicolumn{4}{|l|}{ 2. Had difficulty drinking hot or cold beverages } \\
\hline \multicolumn{4}{|l|}{ 3. Had difficulty eating some foods } \\
\hline \multicolumn{4}{|l|}{ 4. Had difficulty pronouncing any words } \\
\hline \multicolumn{4}{|l|}{ 5. Missed preschool, daycare, or school } \\
\hline How often has your child.... because of dental problems or dental treatments? (Psychological) & $0.4(0.05)$ & $0-8$ & $0-8$ \\
\hline \multicolumn{4}{|l|}{ 6. Had trouble sleeping } \\
\hline \multicolumn{4}{|l|}{ 7. Been irritable or frustrated } \\
\hline $\begin{array}{l}\text { How often has your child ... because of dental problems or dental treatments? (Self-image/social } \\
\text { interaction) }\end{array}$ & $0.1(0.05)$ & $0-8$ & $0-8$ \\
\hline \multicolumn{4}{|l|}{ 8. Avoided smiling or laughing when around other children } \\
\hline \multicolumn{4}{|l|}{ 9. Avoided talking with other children } \\
\hline \multicolumn{4}{|l|}{ Family section } \\
\hline $\begin{array}{l}\text { How often have you or another family member ... because of your child's dental problems or } \\
\text { dental treatments? (Parent distress) }\end{array}$ & $0.4(0.09)$ & $0-8$ & $0-8$ \\
\hline \multicolumn{4}{|l|}{ 10. Been upset } \\
\hline \multicolumn{4}{|l|}{ 11. Felt guilty } \\
\hline How often ... (Family function) & $0.1(0.02)$ & $0-4$ & $0-4$ \\
\hline \multicolumn{4}{|l|}{$\begin{array}{l}\text { 12. Have you or another family member taken time off from work because of your child's dental } \\
\text { problems or dental treatments? }\end{array}$} \\
\hline \multicolumn{4}{|l|}{$\begin{array}{l}\text { 13. Has your child had dental problems or dental treatments that had a financial impact on your } \\
\text { family? }\end{array}$} \\
\hline Total ECOHIS & $1.9(0.21)$ & $0-42$ & $0-41$ \\
\hline
\end{tabular}

ECOHIS early childhood oral health impact scale, ED standard error

Table 3. Univariate and final poisson regression for covariate associated with overall Early Childhood Oral Health Impact Scale.

\begin{tabular}{|c|c|c|c|c|c|c|}
\hline & $\begin{array}{c}\text { With trauma } \\
\text { RR Unadj } \\
(95 \% \mathrm{CI})\end{array}$ & $\begin{array}{c}\text { With trauma } \\
\text { RR Adjust } \\
\text { (95\%Cl) }\end{array}$ & $\begin{array}{l}\text { With AOB } \\
\text { RR Unadj } \\
(95 \% \mathrm{Cl})\end{array}$ & $\begin{array}{l}\text { With AOB } \\
\text { RR Adjust } \\
(95 \% \mathrm{CI})\end{array}$ & $\begin{array}{l}\text { With Caries } \\
\text { RR Unadj } \\
(95 \% \mathrm{Cl})\end{array}$ & $\begin{array}{l}\text { With Caries } \\
\text { RR Unadj } \\
(95 \% \text { CI })\end{array}$ \\
\hline $\begin{array}{l}\text { ECOHIS } \\
\text { (overall scale) }\end{array}$ & $\begin{array}{c}1.64 \\
(0.89-3.02)\end{array}$ & * & $\begin{array}{c}1.58 \\
(1.04-2.38)\end{array}$ & $\begin{array}{c}1.52 \\
(1.03-2.22)^{* *}\end{array}$ & $\begin{array}{c}3.26 \\
(2.29-4.65)\end{array}$ & $\begin{array}{c}2.72 \\
(1.64-4.48)^{\star *}\end{array}$ \\
\hline \multicolumn{7}{|l|}{ Domains } \\
\hline Symptoms & $\begin{array}{c}1.22 \\
(0.70-2.11)\end{array}$ & * & $\begin{array}{c}1.58 \\
(1.04-2.38)\end{array}$ & $\begin{array}{c}1.70 \\
(1.08-2.66)^{\star *}\end{array}$ & $\begin{array}{c}3.41 \\
(2.17-5.38)\end{array}$ & $\begin{array}{c}2.72 \\
(1.64-4.48)^{\star *}\end{array}$ \\
\hline Psychological & $\begin{array}{c}1.11 \\
(0.49-2.50)\end{array}$ & * & $\begin{array}{c}1.15 \\
(0.63-2.08)\end{array}$ & * & $\begin{array}{c}1.97 \\
(1.20-3.24)\end{array}$ & $\begin{array}{c}2.64 \\
(1.57-4.44)^{* *}\end{array}$ \\
\hline $\begin{array}{l}\text { Self-image/ } \\
\text { Social interaction }\end{array}$ & $\begin{array}{c}3.35 \\
(0.88-12.68)\end{array}$ & * & $\begin{array}{c}2.03 \\
(0.62-6.61)\end{array}$ & * & $\begin{array}{c}6.30 \\
(1.86-21.37)\end{array}$ & $\begin{array}{c}3.60 \\
(1.09-11.90)^{* *}\end{array}$ \\
\hline Parental distress & $\begin{array}{c}1.49 \\
(0.75-2.95)\end{array}$ & * & $\begin{array}{c}1.32 \\
(0.77-2.26)\end{array}$ & * & $\begin{array}{c}3.29 \\
(2.02-5.36)\end{array}$ & $\begin{array}{c}2.89 \\
(1.74-4.78) \star *\end{array}$ \\
\hline
\end{tabular}

* Not Fitted in the final model / AOB= Anterior Open Bite / Unadj.= Unadjusted / Adjust.= Adjusted

** Adjusted by child's age, parents'education level, parents' occupation and household income. 


\section{DISCUSSION}

This study evaluated the impact of oral disorders on OHRQoL of preschool children. At the moment, most of the studies that assessed the impact of malocclusion on OHRQoL of preschoolers used convenience sample of patients who sought dental treatment $t^{6,15}$. Therefore, to our knowledge, this is one of the few study that assessed this issue in a representative sample.

The ECOHIS uses response options from parents to assess the frequency in which oral diseases and treatment affect COHRQoL. Child self-report is considered the standard for measuring perceived health related quality of life; however, there are circumstances when parent proxyreport may be indicated ${ }^{16}$, so, it is possible to obtain valid and reliable information from preschool children concerning their OHRQoL using ECOHIS 7,17 . In this study the ECOHIS responses shows that items like trouble sleeping, pain, difficulty to pronounce any words, difficulty in eating some foods were more frequent related with negative impact in OHRQoL. Parents reported being upset and feeling guilty more frequently because of their child's dental problems or treatments. Another study with a representative sample shows a similar results when analyses dental anxiety and distress domain from parents ${ }^{18}$. Regarding the question "missed preschool, daycare or school" there have been many answers "I don't know," probably because the children of our study didn't frequent that places.

This study found that child's age, household income, cavity of dental caries and anterior open bite were correlated with the OHRQoL. However, after the adjustment, only cavity of caries and anterior open bite showed a negative impact in the overall ECOHIS scores. The negative impact of anterior open bite on COHRQoL is the most importat result of the current study. It is suggested that the image of satisfaction expressed by parents with regard to their child could explain the association between anterior open bite and the outcome ${ }^{16}$. A recent study didn't find such association. However, this study was conducted with a convenience sample, what limited extrapolating the results ${ }^{18}$. Therefore, more studies with representative samples are needed.

The role of dentofacial abnormalities in psychosocial well-being and quality of life is well established. Theoretical explanations of the link between malocclusion and OHRQoL are based on the effect of this condition on dissatisfaction with self-image as well as on its impact on adolescents' daily performance. There is evidence that malocclusion can reduce chewing and speech capability, thus affecting an individual's perceptions of oral health.

Nevertheless, the primary impact of malocclusion on quality of life has been reported as being in the domains of emotional and social well-being, which comprise issues related to esthetic components and self-esteem. A disturbance of normal occlusion may reduce social acceptance and induce low self-esteem and poor quality of life by psychosocial pathways. Unesthetic occlusal traits may induce unfavorable social responses among adolescents, such as nicknames and teasing by schoolmates ${ }^{19}$. Others have found that the presence of some occlusal traits is a significant indicator of self-reported bullying among adolescents ${ }^{20}$. Future studies should be conducted to investigate whether orthodontic treatment in preschool children with malocclusion can improve OHRQoL.

We believe that our findings can be due this disorder (anterior open bite) be more easily noticed by parents than others disorders related with occlusion. The low prevalence of overjet and sealing lip inadequate $13.5 \%$ and $10.3 \%$, respectively) may also explain the lack of association between overjet and sealing lip with OHRQoL. Moreover, presence of dental trauma was considered low $(14.1 \%)$, children with dental trauma did not experience more impacts on their quality of life than children with no traumatic dental injury. It suggests that the lower prevalence of dental trauma and the higher prevalence of crown fracture of enamel only could explain such results.

International studies show that clinical criteria for diagnosis overestimate the problems of malocclusion in relation with the individuals' perception ${ }^{21-22}$. This data can be important for planning public health policies for treatment and prevention of this disorder. Quality of life measures, especially ECOHIS for children under 5 years old, have demonstrated to be appropriate to obtain valid and reliable information related with $\mathrm{OHRQOL}{ }^{7-8,15}$.

These study has limitations that could affect the interpretation of the results. First, this study followed a cross-sectional design, which prevents a hypothesis of causality and temporal relations between the outcome and predictor variables. Studies using a longitudinal design could provide a better understanding of the oral disorders influencing the OHRQoL of children. Moreover, a representative sample of preschool children in Brazil was used, obtained by a random selection process at different sample centers around the city. This random process avoided a bias that might occur if, for example, the sample were collected in a clinical setting. Nevertheless, such a 
process provides sound conclusions about the research question for all preschool children living in Santa Maria.

\section{CONCLUSIONS}

In conclusion, anterior open bite presents a negative impact on OHRQoL of preschool children and their parents.

\section{REFERENCES}

1. De Oliveira CM, Sheiham A. Orthodontic treatment and its impact on oral health-related quality of life in Brazilian adolescents. J Orthod. 2004;31(1):20-7. doi: 10.1179/146531204225011364

2 O'Brien K, Wright JL, Conboy F, Macfarlane T, Mandall N. The child perception questionnaire is valid for malocclusions in the United Kingdom. Am J Orthod Dentofacial Orthop. 2006;129(4):536-40. doi: 10.1016/j.ajodo.2004.10.014

3. Bernabe E, Sheiham A, Tsakos G, Messias de Oliveira C. The impact of orthodontic treatment on the quality of life in adolescents: a case-control study. Eur J Orthod. 2008;30(5):51520. doi: 10.1093/ejo/cjn026

4. Brasil. Ministério da Saúde. SBBrasil. Projeto SB Brasil 2003: condições de saúde bucal da população brasileira 2002-2003: resultados principais. Brasília: Ministério da Saúde, 2005 [citado 2014 Set 10]. Disponível em: <http://dtr2001.saude.gov.br/ editora/produtos/livros/pdf/05_0053_M.pdf>.

5. Peres KG, Traebert ES, Marcenes W. Differences between normative criteria and self-perception in the assessment of malocclusion. Rev Saude Publica. 2002;36(2):230-6. doi: 10.1590/S0034-89102002000200016

6. Tessarollo FR, Feldens CA, Closs LQ. The impact of malocclusion on adolescents' dissatisfaction with dental appearance and oral functions. Angle Orthod. 2012;82(3):403-9. doi: 10.2319/031911-195.1

7. Pahel BT, Rozier RG, Slade GD. Parental perceptions of children's oral health: the Early Childhood Oral Health Impact Scale (ECOHIS). Health Qual Life Outcomes. 2007;5:6. doi: 10.1186/1477-7525-5-6

8. Tesch FC, Oliveira BH, Leao A. Semantic equivalence of the Brazilian version of the Early Childhood Oral Health Impact Scale. Cad Saude Publica. 2008;24(8):1897-909. doi: 10.1590/ S0102-311X2008000800018

9. Scarpelli AC, Oliveira BH, Tesch FC, Leao AT, Pordeus IA, Paiva SM. Psychometric properties of the Brazilian version of the Early Childhood Oral Health Impact Scale (B-ECOHIS). BMC Oral Health. 2011;11:19. doi:10.1186/1472-6831-11-19

10. Goettems ML, Ardenghi TM, Romano AR, Demarco FF, Torriani DD. Influence of maternal dental anxiety on oral healthrelated quality of life of preschool children. Qual Life Res. 2011;20(6):951-9. doi: 10.1007/s11136-010-9816-0

11. Piovesan C, Marquezan M, Kramer PF, Bonecker M, Ardenghi TM Socioeconomic and clinical factors associated with caregivers' perceptions of children's oral health in Brazil. Community

\section{Collaborators}

GNR and BCSB were responsible for the data collection and in writing the article. CP, FMM and MMDO participated in the preparation, in discussion of the results and in writing the article. TMA supervised the research and participated in writing the paper.

Dent Oral Epidemiol. 2011;39(3):260-7. doi: 10.1111/j.16000528.2010.00598.x

12. Bonecker M, Marcenes W, Sheiham A. Caries reductions between 1995, 1997 and 1999 in preschool children in Diadema, Brazil. Int J Paediatr Dent. 2002;12(3):183-8. doi: 10.1046/j.1365263X.2002.00352.x

13. O'Brien M. Children's dental health in the United Kingdom 1993. London: Her Majesty's Stationery Office; 1994.

14. Ismail Al, Sohn W, Tellez M, Amaya A, Sen A, Hasson H, et al. The International Caries Detection and Assessment System (ICDAS): an integrated system for measuring dental caries. Community Dent Oral Epidemiol. 2007;35(3):170-8. doi: 10.1111/j.16000528.2007.00347.x

15. Abanto J, Carvalho TS, Mendes FM, Wanderley MT, Bonecker M Raggio DP. Impact of oral diseases and disorders on oral health-related quality of life of preschool children. Community Dent Oral Epidemiol. 2011;39(2):105-14. doi: 10.1111/j.1600-0528.2010.00580.x

16. Reisine S. An overview of self-reported outcome assessment in dental research. J Dent Educ. 1996;60(6):488-93.

17. Lee GH, McGrath C, Yiu CK, King NM. A comparison of a generic and oral health-specific measure in assessing the impact of early childhood caries on quality of life. Community Dent Oral Epidemiol. 2010;38(4):333-9. doi: 10.1111/j.1600-0528.2010.00543.x

18. Aldrigui JM, Abanto J, Carvalho TS, Mendes FM, Wanderley MT, Bonecker M, et al. Impact of traumatic dental injuries and malocclusions on quality of life of young children. Health Qual Life Outcomes. 2011;9:78. doi: 10.1186/1477-7525-9-78

19. Shaw WC, Meek SC, Jones DS. Nicknames, teasing, harassment and the salience of dental features among school children. $\mathrm{Br} J$ Orthod. 1980;7(2):75-80

20. Seehra J, Newton JT, Dibiase AT. Interceptive orthodontic treatment in bullied adolescents and its impact on selfesteem and oral-health-related quality of life. Eur J Orthod. 2012;35(5):615-21. doi: 10.1093/ejo/cjs051

21. Hancock PA, Blinkhorn AS. A comparison of the perceived and normative needs for dental care in 12-year-old children in the northwest of England. Community Dent Health. 1996;13(2):81-5.

22. Mandall NA, McCord JF, Blinkhorn AS, Worthington HV, O'Brien KD. Perceived aesthetic impact of malocclusion and oral selfperceptions in 14-15-year-old Asian and Caucasian children in greater Manchester. Eur J Orthod. 2000;22(2):175-83.

Received on: 10/11/2013

Final version resubmitted on: 20/3/2014

Approved on: 7/5/2014 
